\title{
Positive correlation between circulating cathelicidin antimicrobial peptide (hCAP18/LL-37) and 25 -hydroxyvitamin $D$ levels in healthy adults
}

\author{
Brian M Dixon ${ }^{1}$, Tyler Barker ${ }^{2}$, Toni McKinnon ${ }^{1}$, John Cuomo ${ }^{1}$, Balz Frei $^{3}$, Niels Borregaard ${ }^{4}$ and Adrian F Gombart ${ }^{3 *}$
}

\begin{abstract}
Background: Transcription of the cathelicidin antimicrobial peptide (CAMP) gene is induced by binding of the bioactive form of vitamin $D, 1,25$-dihydroxyvitamin $D$, to the vitamin $D$ receptor. Significant levels of the protein hCAP18/LL-37 are found in the blood and may protect against infection and/or sepsis. We hypothesized that serum vitamin D levels may modulate the circulating levels of hCAP18. Only three studies have shown a positive correlation between circulating 25-hydroxyvitamin D and hCAP18 levels. Here we provide additional evidence for such a correlation in healthy, middle-aged adults.
\end{abstract}

Findings: Serum levels of 25-hydroxyvitamin D $[25(\mathrm{OH}) \mathrm{D}]$ and plasma levels of hCAP18 were determined in 19 healthy middle-aged (mean of 50.1 years) adult men and women. Plasma hCAP18 concentrations correlated with serum 25(OH)D concentrations in subjects with 25(OH)D levels $\leq 32 \mathrm{ng} / \mathrm{ml}(r=0.81, p<0.005)$ but not in subjects with concentrations $>32 \mathrm{ng} / \mathrm{ml}(r=0.19, p=0.63)$.

Conclusions: We conclude that plasma hCAP18 levels correlate with serum 25(OH)D levels in subjects with concentrations of $25(\mathrm{OH}) \mathrm{D} \leq 32 \mathrm{ng} / \mathrm{ml}$ as opposed to those with concentrations $>32 \mathrm{ng} / \mathrm{ml}$ and that vitamin $D$ status may regulate systemic levels of hCAP18/LL-37.

Keywords: Vitamin D, 25-hydroxyvitamin D, Cathelicidin, hCAP18, LL-37, Immunity, Serum, Plasma, CAMP, Infection

\section{Findings}

\section{Background}

CAMP gene expression is important in host defense as mice and humans lacking hCAP18/LL-37 are susceptible to bacterial infections in numerous tissues including the skin, eye, urinary tract, colon and lung [1-11]. Also, increasing hCAP18/LL-37 in these tissues helps reduce and clear infection [12-14]. Collectively, these data strongly implicate expression of the CAMP gene in maintaining adequate host defense. In addition, the LL-37 peptide has additional biological activities that include neutralizing LPS, chemoattraction of leukocytes and promotion of wound healing and angiogenesis [15].

The human cathelicidin antimicrobial peptide (CAMP) gene encodes an $18 \mathrm{kDa}$ propeptide (hCAP18) that is packaged in secondary granules of neutrophils and

\footnotetext{
* Correspondence: adrian.gombart@oregonstate.edu

${ }^{3}$ Linus Pauling Institute and Department of Biochemistry and Biophysics,

Oregon State University, Corvallis OR 97331, USA

Full list of author information is available at the end of the article
}

proteolytically cleaved to generate the mature antimicrobial peptide, LL-37, that kills invading pathogens [16-19]. The CAMP gene is regulated at the level of transcription by the bioactive form of vitamin $\mathrm{D}, 1,25(\mathrm{OH})_{2} \mathrm{D}$, and the vitamin D receptor [20-22]. The hCAP18/LL-37 protein is expressed by a wide array of immune cells $[23,24]$ and tissues that are constantly exposed to microbes including the skin, mouth, airways, intestine and colon and is secreted in saliva, sweat, semen and circulates at high levels in the plasma [25-30]. In vitro administration of $1,25(\mathrm{OH})_{2} \mathrm{D}$ induces $C A M P$ gene expression in immune and other epithelial barrier cells [20-22,31,32]. It has been shown that adequate levels of serum 25(OH)D are required for expression of hCAP18/LL-37 by immune-activated macrophages [33], but the relationship between serum 25(OH)D and plasma hCAP18/LL-37 levels has been unclear [34,35].

The biological importance of circulating hCAP18/ LL-37 is not well understood, but it may play a role in protecting against infection and/or the development of

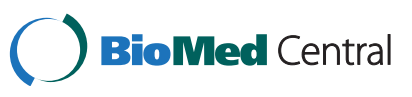


sepsis [20]. Recently we found that dialysis patients with the lowest levels of hCAP18 were at a greater than 2-fold risk of death of infectious causes, but a correlation between 25(OH)D levels and hCAP18 was not observed [34]. Also, in a study of patients with bone disease we did not find a correlation $[34,35]$. On the other hand, severely ill (sepsis and non-sepsis) patients were found to have lower $25(\mathrm{OH}) \mathrm{D}$ and LL-37 than healthy subjects and a positive correlation between vitamin D levels and LL-37 was shown in all populations [36]. More recently, Bhan and colleagues demonstrated that 25(OH)D levels positively correlate with both baseline cathelicidin levels and changes in cathelicidin levels after high-dose ergocalciferol treatment [37]. Interestingly, the positive correlation only existed at $25(\mathrm{OH}) \mathrm{D}$ levels $<32 \mathrm{ng} / \mathrm{ml}$, but not when the levels were $>32 \mathrm{ng} / \mathrm{ml}$ [37]. The relationship between vitamin D status and circulating hCAP18 levels has been inconsistent; therefore, we conducted a prospective study in healthy middle-aged adults to test the hypothesis that serum vitamin D modulates circulating hCAP18 levels.

\section{Materials and methods Subjects}

A total of 19 healthy, volunteer adults were recruited from the greater Salt Lake City metropolitan area $\left(\sim 40^{\circ}\right.$ North latitude). The gender and racial composition, age, vitamin $\mathrm{D}$ intake from a multivitamin and/or dietary sources and average serum $25(\mathrm{OH}) \mathrm{D}$ levels are summarized in Table 1. All subjects were known to be free of disease and were not taking medication or a standalone vitamin $\mathrm{D}$ product, but could have been taking a multivitamin with vitamin D or other supplements that do not contain vitamin D. All serum and plasma were collected from each individual during the month of December. Written informed consent for participation in the study was obtained from participants. The protocol was approved by the ethics review committees at USANA and OSU.

\section{5(OH)D assay}

To determine circulating 25-hydroxyvitamin D levels a modified technique for vitamin $\mathrm{D}$ extraction and measurement was developed [38,39]. Briefly, $100 \mu \mathrm{l}$ of serum was added to $400 \mu \mathrm{l}$ of a 2:1 methanol:chloroform solution containing deuterated 25-hydroxyvitamin D3 as an internal standard (40 ng/ml final concentration). To achieve phase separation, $750 \mu \mathrm{l}$ of ddH2O was added, mixed by vortexer, and centrifuged at 15,000 g for 2 min. The aqueous phase and debris between the two phases were removed, discarded, and the remaining solution dried to completion. The pellet was dissolved in $100 \mu \mathrm{l}$ methanol and analyzed by injecting $10 \mu \mathrm{l}$ into an Agilent HPLC (Series 6410, Model G6410A, Santa Clara, CA, USA). $25(\mathrm{OH}) \mathrm{D}_{3}, 25(\mathrm{OH}) \mathrm{D}_{2}$ and the internal standard were detected on an Agilent tandem mass spectrometer (Series 6410, Model G6410A, Santa Clara, CA, USA) using atmospheric pressure chemical ionization (APCI) detection. Concentrations of $25(\mathrm{OH}) \mathrm{D}_{3}$, $25(\mathrm{OH}) \mathrm{D}_{2}$ and the internal standard were determined relative to authentic standards and corrected for recovery. Average recovery was $92.2 \%$. Intra-day coefficient of variation was $4.7 \%$ and inter-day coefficient of variation was $9.4 \%$. The detection limit was determined to be less than $1 \mathrm{ng} / \mathrm{ml}$ of all analytes. The results were directly compared with two external, FDA-approved, clinical laboratories (Quest Diagnostics and ZRT Laboratory, Beaverton, OR) and levels determined by our assay matched their results (data not shown).

\section{Determination of circulating protein levels}

The levels of hCAP18 $(\mathrm{ng} / \mathrm{ml})$ in each plasma sample were determined using a non-commercial ELISA with a detection limit of $0.084 \mathrm{ng} / \mathrm{ml}$ and an intra- and interassay coefficient of variation of $\leq 6.3 \%$ [30].

\section{Statistical analysis}

Data was checked for normality with a KolmogorovSmirnov test prior to all statistical analyses. Relationships between variables were examined with a Pearson Product Moment Linear correlation. All statistical analyses were performed with SysStat software (SigmaPlot 10.0, SigmaStat 3.5, Chicago, IL). Statistical Significance was set at $\mathrm{p}<0.05$ (for correlation coefficients, $\mathrm{n}=10$, $r \geq 0.632 ; n=9, r \geq 0.666)$.

\section{Results}

When analyzed as one group $(\mathrm{n}=19$; mean age $50.1 \pm$ 8.4), no statistically significant correlation between serum levels of 25(OH)D and plasma hCAP18 was identified (data not shown). Bhan and colleagues reported a positive correlation only existed at 25(OH)D levels $<32 \mathrm{ng} / \mathrm{ml}$, but not with higher levels [37]. Therefore, subjects were separated into two groups based on serum $25(\mathrm{OH}) \mathrm{D}$ levels: those with levels $\leq 32 \mathrm{ng} / \mathrm{ml}$ and those above. Interestingly, plasma hCAP18 concentrations

Table 1 Characteristics of subjects enrolled $(n=19)$

\begin{tabular}{lcccc}
\hline Subjects & Male/Female & Mean age & Ethnicity** $^{*}$ & Mean Vitamin D intake (IU) \\
\hline $\mathbf{1 9}$ & $10 / 9$ & 50.1 & $16 \mathrm{C} / 2 \mathrm{~A} / 1 \mathrm{P}$ & $602.6 \pm 362.3$ \\
\hline
\end{tabular}

${ }^{*}$ C - Caucasian; A - Asian; P - Pacific Islander.

\pm Standard deviations indicated. 
strongly correlated with serum $25(\mathrm{OH}) \mathrm{D}$ concentrations in subjects with 25(OH)D levels $\leq 32 \mathrm{ng} / \mathrm{ml}(\mathrm{r}=$ $0.81, \mathrm{p}<0.005)$ as compared to subjects with concentrations $>32 \mathrm{ng} / \mathrm{ml}(\mathrm{r}=0.19, \mathrm{p}=0.63)$ (Figure $1 \mathrm{~A} \& \mathrm{~B})$. When the cut-off was set at serum levels of $25(\mathrm{OH}) \mathrm{D}$ less than $40 \mathrm{ng} / \mathrm{ml}$, the correlation between $25(\mathrm{OH}) \mathrm{D}$ and hCAP18 in subjects was non-significant $(r=0.43$, $\mathrm{p}=0.14)$. It was not possible to test cut-offs at serum levels of $25(\mathrm{OH}) \mathrm{D}$ less than 25 or $20 \mathrm{ng} / \mathrm{ml}$ as the number of subjects were too low for statistical power.

\section{Discussion}

With the discovery that bio-active forms of vitamin D induce the expression of the CAMP gene, it has been hypothesized that vitamin D status may affect the levels of circulating hCAP18 [20,34]. In a study of dialysis patients, those with the lowest circulating levels of hCAP18 were at a greater than two-fold increased risk of death of infectious causes, but a correlation between serum 25(OH)D and hCAP18 levels was not observed [34].

More recently, Bhan and colleagues discovered a positive correlation in healthy individuals (mean age 39) at $25(\mathrm{OH}) \mathrm{D}$ levels $<32 \mathrm{ng} / \mathrm{ml}$, but not when levels were higher [37]. In their study, the 25(OH)D and cathelicidin concentrations were rank transformed, leaving a possible question as to the biological validity and interpretability of the association. On the other hand, Jeng and colleagues observed a positive association between vitamin $\mathrm{D}$ status and plasma LL-37 in sepsis, critically ill and healthy patients without transforming the data [36]. Interestingly, $100 \%$ of the sepsis patients (mean age $54.0 \pm 17.1$ ), $92 \%$ of the critically ill patients (mean age $56.1 \pm 15.9$ ) and $66.5 \%$ of the healthy individuals (mean age $46.5 \pm 6.1$ ) had serum 25(OH)D levels below $30 \mathrm{ng} / \mathrm{ml} \mathrm{[36].} \mathrm{The}$ authors did not apply a cut-off for analysis, but the majority of their subjects were already below $32 \mathrm{ng} / \mathrm{ml}$, and it is possible that analysis of subjects $>32 \mathrm{ng} / \mathrm{ml} 25$
$(\mathrm{OH}) \mathrm{D}$ would have lacked the statistical power to discern such a trend. Similarly, in a study by AlvarezRodriguez and colleagues of 71 healthy individuals with about two-thirds of participants below $32 \mathrm{ng} / \mathrm{ml}$ serum $25(\mathrm{OH}) \mathrm{D}$, a positive correlation between serum $25(\mathrm{OH})$ $\mathrm{D}$ and LL-37 levels was observed [40]. On the other hand, no relationship between maternal $25(\mathrm{OH})$ D serum levels and LL-37 were detected in cord-blood samples [41] or in patients with active pulmonary tuberculosis [42], but again these studies did not apply a cutoff in the analysis. Interestingly, Alvarez-Rodriguez and colleagues showed that LL-37 levels decreased with age [40]; however, it also has been reported that LL-37 levels increase with age $[43,44]$. A correlation with age could not be examined in this study due to the limited numbers of subjects.

This study confirms the findings of the three earlier studies described above $[36,37,40]$ and further confirms those of Bhan and colleagues [37] that plasma hCAP18 levels correlated with serum $25(\mathrm{OH}) \mathrm{D}$ in subjects with $25(\mathrm{OH}) \mathrm{D}$ concentrations $\leq 32 \mathrm{ng} / \mathrm{ml}$ as opposed to those with concentrations $>32 \mathrm{ng} / \mathrm{ml}$. These studies suggest that there is a threshold for the biological effects of vitamin $\mathrm{D}$, as measured by $25(\mathrm{OH}) \mathrm{D}$, at or around $32 \mathrm{ng} / \mathrm{ml}$ particularly with regard to hCAP18/LL-37 blood levels. To determine the exact threshold (and optimal circulating level of 25(OH)D) for each downstream effect of vitamin D, further research needs to be conducted. Studies with much larger subject numbers and with a broad range of serum $25(\mathrm{OH}) \mathrm{D}$ levels would allow testing of different thresholds to determine if the cutoff is higher or lower than $30-32 \mathrm{ng} / \mathrm{ml}$. This study did not show a correlation at a cutoff of $40 \mathrm{ng} / \mathrm{ml} 25(\mathrm{OH}) \mathrm{D}$, but we could not test lower cutoffs due to insufficient subject numbers.

Given the nature of the relationship between serum 25(OH)D and hCAP18/LL-37 levels, it is possible that vitamin $\mathrm{D}$ supplementation or exposure to sunlight to
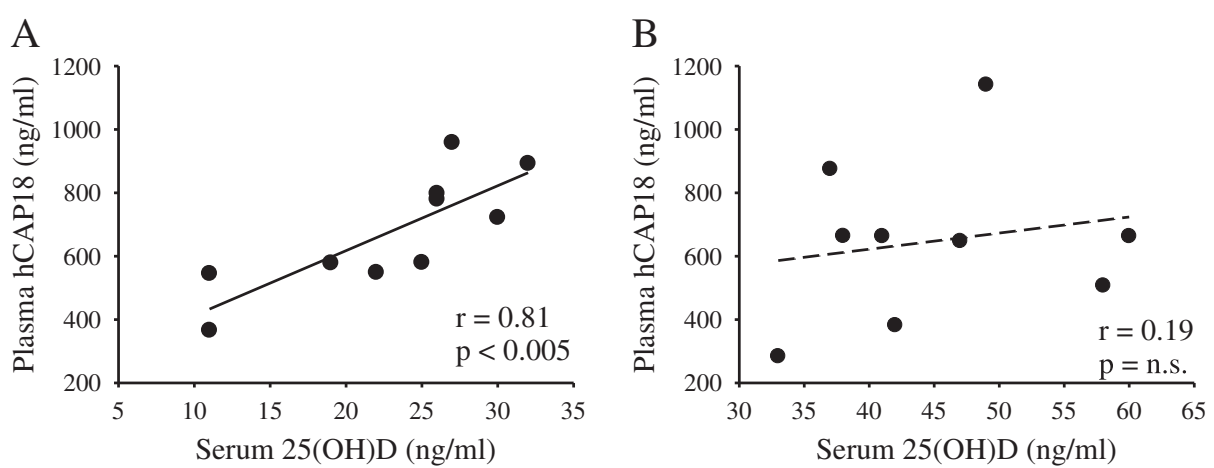

Figure 1 Correlation between serum 25(OH)D and plasma hCAP18 levels. Plasma hCAP18 concentrations (ng/ml) correlated with serum $25(\mathrm{OH})$ D concentrations $(\mathrm{ng} / \mathrm{ml}$ ) in subjects with $25(\mathrm{OH}) \mathrm{D} \leq 32 \mathrm{ng} / \mathrm{ml}$ (panel $\mathbf{A}, \mathrm{n}=10$, solid regression line) but not in subjects with concentrations $>32 \mathrm{ng} / \mathrm{ml}$ (panel $\mathbf{B}, \mathrm{n}=9$, dotted regression line). 
synthesize vitamin $\mathrm{D}$ may provide a means to raise systemic levels of hCAP18/LL-37, thus enhancing protection against infection and/or sepsis. In support of this, in vivo supplementation of individuals with serum $25(\mathrm{OH}) \mathrm{D}$ levels $<32 \mathrm{ng} / \mathrm{ml}$ resulted in an increase in hCAP18 levels in those individuals showing the greatest increase in serum $25(\mathrm{OH}) \mathrm{D}$ [37]. In another study, supplementation of normal and atopic dermatitis (AD) patients with 4,000 IU oral vitamin D3 (cholecalciferol) for 21 days resulted in a statistically significant increase in cathelicidin expression in the AD lesions [45]. It was not determined if supplementation improved immunologic outcomes in these studies; therefore, future randomized controlled trials are needed to establish an immune enhancing role for vitamin D supplementation and to determine optimal circulating levels.

\section{Competing interests}

BD, TM and JC are employed by USANA Health Sciences.

\section{Authors' contributions}

$B D, J C, B F$ and AFG conceived of and designed the study. BD, TM, JC, BF, NB and AFG supervised and/or were directly involved in the acquisition of data. $T B, B D$ and $A F G$ analyzed the data. TB, BD and AFG drafted the initial manuscript and all co-authors reviewed the manuscript for important intellectual content and read and approved the final version.

\section{Acknowledgements}

We thank Charlotte Horn and Deborah Hobbs for technical assistance and Mary Fantacone for critically reading the manuscript. This project was supported by USANA Health Sciences Inc., Salt Lake City, UT, and the National Institute of Allergy and Infectious Diseases at the National Institutes of Health [5R01Al065604-06 to A.F.G.].

\section{Author details}

'USANA Health Sciences, Inc, 3838 West Parkway Boulevard, Salt Lake City UT 84120, USA. ${ }^{2}$ Sport Science Department, The Orthopedic Specialty Hospital, Murray UT 84107, USA. ${ }^{3}$ Linus Pauling Institute and Department of Biochemistry and Biophysics, Oregon State University, Corvallis OR 97331, USA. ${ }^{4}$ The Granulocyte Research Laboratory, Department of Hematology, National University Hospital, Copenhagen, Denmark.

Received: 6 September 2012 Accepted: 19 October 2012 Published: 24 October 2012

\section{References}

1. Nizet V, Ohtake T, Lauth X, Trowbridge J, Rudisill J, Dorschner RA, Pestonjamasp V, Piraino J, Huttner K, Gallo RL: Innate antimicrobial peptide protects the skin from invasive bacterial infection. Nature 2001, 414(6862):454-457.

2. Huang LC, Reins RY, Gallo RL, McDermott AM: Cathelicidin-deficient (Cnlp -/- ) mice show increased susceptibility to Pseudomonas aeruginosa keratitis. Invest Ophthalmol Vis Sci 2007, 48(10):4498-4508.

3. Chromek M, Slamova Z, Bergman P, Kovacs L, Podracka L, Ehren I, Hokfelt T, Gudmundsson GH, Gallo RL, Agerberth B, et al: The antimicrobial peptide cathelicidin protects the urinary tract against invasive bacterial infection. Nat Med 2006, 12(6):636-641.

4. limura M, Gallo RL, Hase K, Miyamoto Y, Eckmann L, Kagnoff MF: Cathelicidin mediates innate intestinal defense against colonization with epithelial adherent bacterial pathogens. J Immunol 2005, 174(8):4901-4907.

5. Yu FS, Cornicelli MD, Kovach MA, Newstead MW, Zeng X, Kumar A, Gao N, Yoon SG, Gallo RL, Standiford TJ: Flagellin stimulates protective lung mucosal immunity: role of cathelicidin-related antimicrobial peptide. $J$ Immunol 2010, 185(2):1142-1149.
6. Ong PY, Ohtake T, Brandt C, Strickland I, Boguniewicz M, Ganz T, Gallo RL, Leung DY: Endogenous antimicrobial peptides and skin infections in atopic dermatitis. N Engl J Med 2002, 347(15):1151-1160.

7. Putsep K, Carlsson G, Boman HG, Andersson M: Deficiency of antibacterial peptides in patients with morbus Kostmann: an observation study. Lancet 2002, 360(9340):1144-1149.

8. Gombart AF, Koeffler HP: Neutrophil specific granule deficiency and mutations in the gene encoding transcription factor C/EBP(epsilon). Curr Opin Hematol 2002, 9(1):36-42.

9. Yang YH, Zheng GG, Li G, Zhang B, Song YH, Wu KF: Expression of LL-37/hCAP-18 gene in human leukemia cells. Leuk Res 2003, 27(10):947-950.

10. An LL, Ma XT, Yang YH, Lin YM, Song YH, Wu KF: Marked reduction of LL-37/hCAP-18, an antimicrobial peptide, in patients with acute myeloid leukemia. Int J Hematol 2005, 81(1):45-47.

11. Steinstraesser L, Oezdogan $Y$, Wang SC, Steinau HU: Host defense peptides in burns. Burns 2004, 30(7):619-627.

12. Bals R, Weiner DJ, Moscioni AD, Meegalla RL, Wilson JM: Augmentation of innate host defense by expression of a cathelicidin antimicrobial peptide. Infect Immun 1999, 67(11):6084-6089.

13. Jacobsen F, Mittler D, Hirsch T, Gerhards A, Lehnhardt M, Voss B, Steinau HU, Steinstraesser L: Transient cutaneous adenoviral gene therapy with human host defense peptide hCAP-18/LL-37 is effective for the treatment of burn wound infections. Gene Ther 2005, 12(20):1494-1502

14. Raqib R, Sarker P, Bergman P, Ara G, Lindh M, Sack DA, Nasirul Islam KM, Gudmundsson GH, Andersson J, Agerberth B: Improved outcome in shigellosis associated with butyrate induction of an endogenous peptide antibiotic. Proc Natl Acad Sci USA 2006, 103(24):9178-9183.

15. Gombart AF: The vitamin D-antimicrobial peptide pathway and its role in protection against infection. Future Microbiol 2009, 4(9):1151-1165.

16. Agerberth B, Gunne H, Odeberg J, Kogner P, Boman HG, Gudmundsson GH: FALL-39, a putative human peptide antibiotic, is cysteine-free and expressed in bone marrow and testis. Proc Natl Acad Sci USA 1995, 92(1):195-199.

17. Larrick JW, Hirata M, Balint RF, Lee J, Zhong J, Wright SC: Human CAP18: a novel antimicrobial lipopolysaccharide-binding protein. Infect Immun 1995, 63(4):1291-1297.

18. Cowland JB, Johnsen AH, Borregaard N: hCAP-18, a cathelin/probactenecin-like protein of human neutrophil specific granules. FEBS Lett 1995, 368(1):173-176.

19. Sorensen $\mathrm{OE}$, Follin $\mathrm{P}$, Johnsen $A H$, Calafat J, Tjabringa GS, Hiemstra PS, Borregaard N: Human cathelicidin, hCAP-18, is processed to the antimicrobial peptide LL-37 by extracellular cleavage with proteinase 3 . Blood 2001, 97(12):3951-3959.

20. Gombart AF, Borregaard N, Koeffler HP: Human cathelicidin antimicrobial peptide (CAMP) gene is a direct target of the vitamin $D$ receptor and is strongly up-regulated in myeloid cells by 1,25-dihydroxyvitamin D3. FASEB J 2005, 19(9):1067-1077.

21. Wang TT, Nestel FP, Bourdeau V, Nagai $Y$, Wang Q, Liao J, Tavera-Mendoza L, Lin R, Hanrahan JW, Mader S, et al: Cutting edge: 1,25-dihydroxyvitamin D3 is a direct inducer of antimicrobial peptide gene expression. $J$ Immunol 2004, 173(5):2909-2912.

22. Weber $\mathrm{G}$, Heilborn JD, Chamorro Jimenez $\mathrm{Cl}$, Hammarsjo A, Torma $\mathrm{H}_{\text {, }}$ Stahle M: Vitamin D induces the antimicrobial protein hCAP18 in human skin. J Invest Dermatol 2005, 124(5):1080-1082.

23. Agerberth B, Charo J, Werr J, Olsson B, Idali F, Lindbom L, Kiessling R, Jornvall $H$, Wigzell $H$, Gudmundsson $\mathrm{GH}$ : The human antimicrobial and chemotactic peptides LL-37 and alpha-defensins are expressed by specific lymphocyte and monocyte populations. Blood 2000, 96(9):3086-3093.

24. Sorensen O, Arnljots K, Cowland JB, Bainton DF, Borregaard N: The human antibacterial cathelicidin, hCAP-18, is synthesized in myelocytes and metamyelocytes and localized to specific granules in neutrophils. Blood 1997, 90(7):2796-2803.

25. Frohm Nilsson M, Sandstedt B, Sorensen O, Weber G, Borregaard N, Stahle-Backdahl M: The human cationic antimicrobial protein (hCAP18), a peptide antibiotic, is widely expressed in human squamous epithelia and colocalizes with interleukin-6. Infect Immun 1999, 67(5):2561-2566 
26. Bals R, Wang X, Zasloff M, Wilson JM: The peptide antibiotic LL-37/ hCAP-18 is expressed in epithelia of the human lung where it has broad antimicrobial activity at the airway surface. Proc Natl Acad Sci USA 1998, 95(16):9541-9546.

27. Murakami M, Ohtake T, Dorschner RA, Gallo RL: Cathelicidin antimicrobial peptides are expressed in salivary glands and saliva. J Dent Res 2002, 81(12):845-850.

28. Malm J, Sorensen O, Persson T, Frohm-Nilsson M, Johansson B, Bjartell A, Lilja H, Stahle-Backdahl M, Borregaard N, Egesten A: The human cationic antimicrobial protein (hCAP-18) is expressed in the epithelium of human epididymis, is present in seminal plasma at high concentrations, and is attached to spermatozoa. Infect Immun 2000, 68(7):4297-4302.

29. Andersson E, Sorensen OE, Frohm B, Borregaard N, Egesten A, Malm J: Isolation of human cationic antimicrobial protein-18 from seminal plasma and its association with prostasomes. Hum Reprod 2002, 17(10):2529-2534.

30. Sorensen O, Cowland JB, Askaa J, Borregaard N: An ELISA for hCAP-18, the cathelicidin present in human neutrophils and plasma. $J$ Immunol Methods 1997, 206(1-2):53-59.

31. Gombart AF, O'Kelly J, Saito T, Koeffler HP: Regulation of the CAMP gene by $1,25(\mathrm{OH}) 2 \mathrm{D} 3$ in various tissues. J Steroid Biochem Mol Biol 2007, 103(3-5):552-557.

32. Schauber J, Dorschner RA, Yamasaki K, Brouha B, Gallo RL: Control of the innate epithelial antimicrobial response is cell-type specific and dependent on relevant microenvironmental stimuli. Immunology 2006 118(4):509-519.

33. Liu PT, Stenger S, Li H, Wenzel L, Tan BH, Krutzik SR, Ochoa MT, Schauber J, Wu K, Meinken C, et al: Toll-like receptor triggering of a vitamin D-mediated human antimicrobial response. Science 2006, 311(5768):1770-1773.

34. Gombart AF, Bhan I, Borregaard N, Tamez H, Camargo CA Jr, Koeffler HP, Thadhani R: Low plasma level of cathelicidin antimicrobial peptide (hCAP18) predicts increased infectious disease mortality in patients undergoing hemodialysis. Clin Infect Dis 2009, 48(4):418-424.

35. Adams JS, Ren S, Liu PT, Chun RF, Lagishetty V, Gombart AF, Borregaard N, Modlin RL, Hewison M: Vitamin d-directed rheostatic regulation of monocyte antibacterial responses. J Immunol 2009, 182(7):4289-4295.

36. Jeng L, Yamshchikov AV, Judd SE, Blumberg HM, Martin GS, Ziegler TR, Tangpricha $V$ : Alterations in vitamin D status and anti-microbial peptide levels in patients in the intensive care unit with sepsis. J Trans/ Med 2009, 7:28.

37. Bhan I, Camargo CA Jr, Wenger J, Ricciardi C, Ye J, Borregaard N, Thadhani R: Circulating levels of 25-hydroxyvitamin D and human cathelicidin in healthy adults. J Allergy Clin Immunol 2011, 127(5):1302-1304. e1. Epub 2011 Feb 9. No abstract available. PMID: 21310475.

38. WJ BEaD: A rapid method of total lipid extraction and purification. Can $J$ Biochem Physiol 1959, 37:911-917.

39. Jones G: Assay of vitamins D2 and D3, and 25-hydroxyvitamins D2 and D3 in human plasma by high-performance liquid chromatography. Clin Chem 1978, 24(2):287-298.

40. Alvarez-Rodriguez L, Lopez-Hoyos M, Garcia-Unzueta M, Amado JA, Cacho PM, Martinez-Taboada VM: Age and low levels of circulating vitamin $D$ are associated with impaired innate immune function. J Leukoc Biol 2012, 91(5):829-838.

41. Mandic Havelka A, Yektaei-Karin E, Hultenby K, Sorensen OE, Lundahl J, Berggren $V$, Marchini G: Maternal plasma level of antimicrobial peptide LL37 is a major determinant factor of neonatal plasma LL37 level. Acta Paediatr 2010, 99(6):836-841

42. Yamshchikov AV, Kurbatova EV, Kumari M, Blumberg HM, Ziegler TR, Ray SM, Tangpricha V: Vitamin D status and antimicrobial peptide cathelicidin (LL-37) concentrations in patients with active pulmonary tuberculosis. Am J Clin Nutr 2010, 92(3):603-611.

43. Jiang H, Schiffer E, Song Z, Wang J, Zurbig P, Thedieck K, Moes S, Bantel H, Saal N, Jantos J, et al: Proteins induced by telomere dysfunction and DNA damage represent biomarkers of human aging and disease. Proc Natl Acad Sci USA 2008, 105(32):11299-11304.
44. Jiang H, Chen W, Qu L, Chen Y, He Q, Wang H, Wu J, Shou Z, Ju Z, Chen J: ELISA for aging biomarkers induced by telomere dysfunction in human plasma. J Biomed Biotechnol 2010, 2010:121947.

45. Hata TR, Kotol P, Jackson M, Nguyen M, Paik A, Udall D, Kanada K Yamasaki K, Alexandrescu D, Gallo RL: Administration of oral vitamin D induces cathelicidin production in atopic individuals. J Allergy Clin Immunol 2008, 122(4):829-831.

doi:10.1186/1756-0500-5-575

Cite this article as: Dixon et al:: Positive correlation between circulating cathelicidin antimicrobial peptide (hCAP18/LL-37) and 25hydroxyvitamin D levels in healthy adults. BMC Research Notes 2012 5:575.

\section{Submit your next manuscript to BioMed Central and take full advantage of:}

- Convenient online submission

- Thorough peer review

- No space constraints or color figure charges

- Immediate publication on acceptance

- Inclusion in PubMed, CAS, Scopus and Google Scholar

- Research which is freely available for redistribution 